\title{
Doing Business the Chinese Way? On Manadonese Chinese Entrepreneurship in North Sulawesi
}

\author{
Michael Jacobsen
}

\begin{abstract}
This article argues and documents that diasporic networking and guanxi relationships in North Sulawesi Province in East Indonesia are not essential for doing business within the Chinese business community. The main argument forwarded is that guanxi governed business networks are but one strategy among several other business strategies employed, when engaging in inter-ethnic and intra-ethnic business transactions. Furthermore, a discussion of the relationship between local Chinese and non-Chinese business environment as well as of the inter-ethnic environment in general constitutes a framework for how to position the Chinese in an overall societal context. Of special interest in this connection are questions of inter-ethnic integration versus assimilation together with questions of descent and ethnic classification in the relation to the surrounding non-Chinese community ${ }^{1}$.
\end{abstract}

\section{Introduction}

In any discussion of ethnic Chinese business practices in Southeast Asia, two interrelated themes immediately crop up. They are the cohesive nature of the ethnic Chinese diaspora and the pervasive practice of guanxi in Chinese business transactions. ${ }^{2}$ In relation to the former, McKeown writes that it can be conceived of as constituting an international router for ethnic Chinese (business) networks (McKeown 2001), while Kotkin states that the Chinese diaspora is characterized by an enduring sense of group identification and global linkages (Kotkin 1992; Bolt 2000). Callahan goes a step further, arguing that the comparative advantage of the Chinese diaspora is its Confucian reading of capitalism, which results in low transaction costs when conducting intra-ethnic business in China and Southeast Asia, especially in places where the legal system in terms of (trade) rules and regulations is underdeveloped (Callahan 2002). According to these authors, the Chinese diaspora is highly conducive as an international channel for Chinese entrepreneurs as well as for Chinese migrants and sojourners. 
The inner workings of the Chinese diaspora are often defined in terms of transnational as well as national relationships, revolving around language, ethnicity and kinship affiliations within and between different Chinese communities. This, it is argued, gives it a comparative advantage over other types of networks due to the perceived common Confucian strength of mind. At the core of these networks, Luo (2000) and Yang (1994) maintain, is the so-called guanxi relationship that typifies the basic model of interpersonal relations, including those conducted in a business context (Weidenbaum and Hughes 1996).

Not every observer of the Chinese diaspora, however, subscribes to these perceptions of business being conducted in the 'Chinese way'. For example, Gomez and Hsiao write that individual ethnic Chinese entrepreneurs do not necessarily make business deals on the basis of guanxi relations within a diasporic matrix. They maintain that Chinese entrepreneurs have dealings with whoever can provide them with a profit, be they intra-ethnic or inter-ethnic business 'others', thus linking up to the appropriate Chinese or non-Chinese business communities within or outside their country of residence (Gomez and Hsin-Huang Hsiao 2001). Furthermore, they are critical of the literature that highlights the importance of the culturally infused dynamics of ethnic Chinese entrepreneurs (Kotkin 1992; Redding 1993; Weidenbaum and Hughes 1996; Hamilton 1999; Yeung 1998, 2004). Following the critique by Gomez and Hsiao (2001), Yao Souchou contests the hypothesis that the institutions, norms and practices of ethnic Chinese are the main reason for the growth of their enterprises (Yao 2002). Ultimately, they all question whether Chinese entrepreneurs have depended primarily on business networks based on shared identities to develop their corporate base. They thus distance themselves from the massive literature on the importance of the Chinese diaspora, guanxi relationships and their influence on ethnic Chinese business practices.

Following the critical approach outlined above, this article argues and documents that diasporic networking and guanxi relationships in an East Indonesian context are not essential for doing business within the ethnic Chinese business environment. The main argument propounded here is that guanxi-governed business networks are but one strategy among a number of others employed, when engaging in inter-ethnic and intra-ethnic business transactions. On a more general level, these findings confirm Dirlik's proposition that Chinese business practices conceived of as being based on guanxi-engineered interpersonal relations constitute an ethnicization of capitalist practices 
and not a specific Chinese economy paralleling global capitalism (Dirlik 1996).

Returning to the discussion of the cohesiveness generally attributed to the Chinese diaspora, this article subscribes to the idea that a diaspora constitutes a decentred and multileveled ideational network that allows people to move in and out of a given diaspora depending on their current social and political situation. ${ }^{3}$ An adherence to a given diaspora thus depends on relative social, economic and political contextual givens. An understanding of diaspora in this article thus does not depend on systemic network approaches, but rather on how and under what circumstances de facto socio-political developments may influence an ethnic Chinese entrepreneur's relationship to a given diaspora. Such an approach demands that we first analyse and distil those social, political and economic forces that have the capacity to initiate change in the societal embeddedness of the ethnic Chinese. This is achieved in this article by analysing the interaction between the latter and their community of residence.

This article concentrates on the ethnic Chinese business community in Manado, the provincial capital of North Sulawesi, eastern Indonesia. As there is no written research material on this topic available for this province, two pieces of fieldwork conducted in March and June 2003 will constitute the empirical background for this study. In order to focus the research, three sectors within the ethnic Chinese retail sector (clothing, electronics and IT stores that sell computer hardware and software to both public and private customers), were selected for study. The topics discussed with representatives from these three sectors ranged from early migration patterns and family history to business strategies and potential connections to the Chinese diaspora. Finally, the relationship between the local Chinese and non-Chinese business environment and the inter-ethnic environment in general provides a matrix to position the ethnic Chinese in an overall societal context. Of special interest in this connection are questions of inter-ethnic integration versus assimilation, together with questions of descent and ethnic classification in the relation to the surrounding non-Chinese community.

The article opens with a vivid description of the Manadonese Chinese in contemporary Manado. It then focuses on the societal processes that regulate the relationship between the Chinese and the Minahasa, the latter being the dominant ethnic group in North Sulawesi Province. ${ }^{4}$ The three retail sectors singled out for study are subsequently compared in detail. The article closes with a discussion of whether the role guanxi 
relations and diasporic affiliations play in the contemporary Manadonese Chinese business environment is superseded in importance by questions of integration versus assimilation in regulating inter-ethnic relations.

\section{On the Chinese Community in Contemporary Manado}

Manadonese Chinese do not like to use the term Kampung Cina, that is, China Town, to describe the original centre of the Chinese business community in Manado. They prefer to use the words 'downtown' or 'centre'. The problem with the word Kampung Cina is that it establishes a difference between them and the Minahasa, a difference that they are keen to play down. As I shall elaborate upon later, every single Chinese trader in the retail sector maintains that there is a good relationship between them and the Minahasa. Another important point to note is a clear division within the Chinese community itself along Peranakan-Totok lines. ${ }^{5}$ It is an insult to call Peranakans Totoks, as it indicates they are newcomers and thus not really integrated, not to talk of assimilated, into the indigenous community. Finally, the word Cina in Bahasa Indonesia has a derogatory connotation. The correct word to use when approaching a Manadonese Chinese is 'Tionghoa', as it is more neutral. If you use 'Cina', then you are referring to Mainland Chinese or newly arrived immigrants and thus not to a local Chinese. In what follows, every effort has been taken to comply with these unwritten semantic rules, with one exception. The exception is that I shall the term Kampung Cina as an analytical tool, as it is an effective way to distinguish between the different commercial centres that exist within Manado.

Kampung Cina lies in the centre of Manado, a city of 372,598 population constituting 19 percent of the total population $(1,972,738)$ in North Sulawesi Province, according to a year 2000 population census. Kampung Cina is divided into different sectors that specialize in various kinds of wholesale and retail stores. As mentioned above, this survey focuses on the clothing, electronic and IT retail sectors. ${ }^{6}$ Those who participated in the survey mainly have their stores within the Kampung, particularly those in the clothing sector. A few of the electronic retail stores can be found just outside the Kampung where there is more space, while all the IT stores are found in greater Manado, that is, outside Kampung Cina.

In general, the stores can be divided into two main types. The first is the traditional Chinese one, where the store is on the ground floor and the family occupies the first and second floor, thus living among the stock of items for sale. Younger people generally run the second 
type of store, which is detached from the private residence. They tend to live outside Kampung Cina in nuclear families but have their stores within it. Besides clothing, electronic and IT retail stores, Kampung Cina accommodates a huge variety of restaurants and food stores together with wholesale stores that specialize in all sorts of iron pipes and metal fittings, different types of wood, rattan baskets and furniture, and various household articles. In addition, there are garages that fix and sell spare parts for many different types of engines (especially motorcycles and cars). Sometimes retail and wholesale stores are lumped together into one building, which offers what can be termed 'across-the-board solutions' for private homes, government offices and private businesses. The overall impression of Kampung Cina, beyond the huge variety of stores, is that of a cacophony of music and a constant flow of people and cars. The narrow streets serve an endless flow of trucks, buses, private cars and horse-drawn carts dragging goods from one end of the Kampung to the other and beyond. Added to this colourful medley of activities is the noise and smell of poorly maintained cars together with huge piles of garbage consisting of plastic bags and bottles mixed with the sweet smell of rotting fruit and other types of leftovers.

When entering, for example, a clothing store, one finds oneself in a narrow but long room housing all sorts of material - clothing for men and women, umbrellas, gloves, etc. Generally a member of the family, usually the wife or daughter of the owner, sits close by the entrance or in the back of the store, answering the telephone and taking care of the everyday business transactions. The other children of the owner may also work there, together with some local non-Chinese Manadonese who serve the customers. In many cases, the owner may also own the store next door or one further down the street. This might be the one that their great-grandparents opened when first arriving in Manado during the 1920s or 1930s. The original store is usually run by the parents, while one of their sons might start up a new store in Kampung Cina or just outside it. If the family has a store in one of the new shopping malls currently being built by wealthy Chinese or Javanese business people on the new boulevard that runs along Manado Bay, then it is generally the younger generation who run it. The parents tend to take care of the old store(s) in Kampung Cina - perhaps for sentimental reasons.

In between the clothing stores in Kampung Cina, there might be a store selling electronic goods. This generally consists of a big room with a family member of the owner sitting close by the door or in the back of the room. As in the case of the clothing store, it is usually the wife or 
daughter (seldom the son) of the owner who sits there. The husband, perhaps together with his son(s), might be in Jakarta or Surabaya buying new stock for the store or looking for business opportunities to establish a new store in other parts of Kampung Cina, in Manado proper or down at the boulevard along Manado Bay. The store will contain dozens of different types of TV sets, radios and CD players together with video/DVD players, not necessarily the major international brands such as Sony, Toshiba, Aiwa or Onkyo, but cheap Indonesian, Chinese and Korean brands that are more affordable for the local population. Besides these articles, an array of different types of fans together with dehumidifiers, refrigerators, all sorts of electronic tools for the kitchen and a multitude of household clocks can be found. In this type of outlet too, various family members together with non-Chinese Manadonese staff help in the day-to-day running of the store.

Outside on the streets, besides very loud music blaring out from the electronic stores to grab customers' attention, there are many street vendors, the so-called 'five foot retailers' or Pedagang Kaki Lima in Bahasa Indonesia. These people are mainly Muslims and originate from the newly established Gorontalo Province. From their small stalls they noisily proclaim to passers-by the excellence of the wares they are selling, be it fish, fruit, vegetables, watches, sunglasses, cheap CDs, DVDs, cassettes, etc. Or they try to show the quality of the goods to potential customers by turning on a small TV set or DVD player at high volume. Some tensions exist between these vendors and the mainly Christian Chinese store owners, whose businesses are located just behind the rows of the 'five foot retailers'. The Chinese retailers complain firstly that these stalls are luring away their customers; secondly, that they obscure the view to their window displays so that the customers cannot see them from their cars. Furthermore, the retailers also complain that they are paying rates, sewage charges, water and electricity bills, while the small stalls, besides blocking the streets, pay for nothing.

The Chinese retailers have protested about this to the Manadonese authorities, and the police have on several occasions tried to chase away the stall owners but they always return. On the other hand, the 'five foot retailers' have turned down an offer from the municipality to have their own mall where they could create their particular marketplace. The main reason for rejecting this offer is, according to the stall owners, that their particular types of stall have always been there and that the whole environment is what makes it attractive to the customers; that their presence is what makes Kampung Cina a fascinating and lively place. 
This problem is, however, not unique to Manado. During a visit to the industrial centre of Bitung municipality $45 \mathrm{~km}$ east of Manado, Chinese retailers also complained that the 'five foot retailers' were obscuring the view to their stores and luring away potential customers. As in Manado, most of the stall owners originate from Gorontalo Province, a 12-hour bus ride away.

Back in Manado and Kampung Cina, the Chinese retailers are of course not confined to the Kampung. It is mainly the small and medium-size retail and wholesale stores that can be found there. Spread throughout Manado one finds the better-off Chinese who consider Kampung Cina as too crowded, noisy and polluted. Here they have set up their big stores and homes, thus mingling with the local Manadonese business community. They sell cars and motorbikes and it is also here that the major Chinese-owned wholesale and retail stores such as supermarkets, hotels and mini shopping malls can be found. According to those we spoke to (both Chinese and non-Chinese), it is the Chinese who own most of the wholesale and retail sector in Manado. Outside Kampung Cina the small Gorontalese-run 'five foot retailers' cannot be found. There is simply not room for them, as this is also where the major and very busy roads are located - it would simply be too dangerous for them to set up their stalls here.

The Minahasa, the dominant ethnic group in North Sulawesi Province, and certainly within the Minahasa regencies, have concentrated their efforts on getting jobs within the bureaucracy and the political institutions and organizations. Some say that they are not good traders and that they have been more or less out-competed by the Gorontalese and the Chinese. Others say that the Minahasa are too lazy to take up the challenge, as they were previously spoiled by the fertility of the land and a benevolent Dutch colonialism, and thus were not required to work too hard. Whatever the reason, it is a fact that the Chinese predominate in wholesale, retail, and the major businesses in Manado and in the Minahasa regencies. The petty trade is more or less monopolized by Gorontalese Muslims and, of course, by some entrepreneurial Manadonese, but the latter are certainly not in the majority.

Despite these divisions between the ethnic groups, almost all the Manadonese Chinese said that they felt not only integrated but also quite assimilated into the local Minahasa communities. This was owing to cultural factors, together with some degree of intermarriage spanning several generations. I shall return to these points later on in greater detail. At present it suffices to stress the positive and harmonious inter- 
ethnic relationship that exists between Manadonese Chinese and local Minahasans. As such, it stands in marked contrast to the relationship between ethnic Chinese and local Muslims in South Sulawesi.

For example, according to one Christian Chinese informant who originally came from South Sulawesi Province but is currently living permanently in North Sulawesi, in South Sulawesi the Chinese only marry amongst themselves, as the Muslim environment there is very hostile towards the Chinese. Every generation of South Sulawesi Chinese, especially the Christian ones, had experienced at least one riot directed against themselves, their families and businesses. This is one of the major reasons why many had moved with their families to North Sulawesi. Even though they now live in North Sulawesi and feel well integrated into the Minahasa community, they still prefer to marry amongst themselves for security reasons. This practice, however, is not as strictly enforced as in South Sulawesi and elsewhere in Indonesia, as a number of Manadonese Chinese men have married Minahasa women. Interestingly, only a tiny fraction of Manadonese Chinese women have married Minahasa men, as most of them prefer to marry Chinese men. The main reason is that Chinese women do not find Minahasa men entrepreneurial enough compared to their Chinese counterparts. The security that Minahasa men otherwise could provide the Chinese women is thus not enough to compete with a social status that is based on wealth and intra-ethnic preferences.

Religious difference and feelings of jealousy towards those who have proved themselves more successful in business have undoubtedly created hostility between the Chinese and Muslims in South Sulawesi. Other informants pointed out that the Chinese in South Sulawesi are quite arrogant, as they perceive the local population as inferior. ${ }^{7}$ This attitude has infuriated the local Muslims to such an extent that they have tended to make the Chinese scapegoats for all the bad things that happen in their communities. So in a sense, the negative relationship between Chinese and Muslims in this part of Sulawesi has a duality to it: on the one hand, the two parties loathe each other because of negative stereotyping; yet on the other hand, they need each other at least in the economic sector.

\section{Religious Dimensions of Processes of Integration and Assimilation}

Despite the very positive comments expressed in relation to the Manadonese Chinese's assimilation into the local Minahasa communities, 
it seems as if they constitute a kind of 'window dressing' that covers up a much more complex inter-ethnic relationship. For example, the constant emphasis on the success of inter-ethnic assimilation and preference for inter-ethnic relationships, actually underscores the fact that a boundary still exists between the Chinese and the Minahasa.

Even though the Chinese and the Minahasa constantly declare that they mix very well, there is a tendency for the Chinese to cultivate intraethnic relationships. In Manado, for instance, there is an architecturally elaborate and expensive church designated to the Christian Evangelical Church in Minahasa (GMIM). It was paid for by wealthy Chinese, who make up about 90 percent of the congregation. One of the reasons for preferring to link up to other Chinese is, as indicated above, past negative inter-ethnic experiences that continue to haunt them. I am here referring to those Chinese who came to North Sulawesi from other places in Indonesia, first and foremost Jakarta in Java, Makassar and Poso in southern and central Sulawesi, and Ambon in the Moluccas. Besides being made scapegoats at times of political and economic difficulty, many of these Chinese lost family members in the late 1950s and early 1960s due to politically engineered events. ${ }^{8}$ Consequently, the Chinese are rather apprehensive towards outsiders. A similar sense of ambivalence towards all things Chinese can be sensed among the Minahasa. One of my Minahasa respondents, who showed a keen interest in my work on the Manadonese Chinese, asked me several times during my fieldwork what the Chinese were doing, how they regarded the Minahasa, and where they stood in terms of local and national politics. These enquiries revealed a subtle barrier between the Minahasa and the Chinese, which exists just beneath the otherwise harmonious inter-ethnic surface. On the basis of such statements, one may conclude that the Chinese in North Sulawesi Province are more integrated than assimilated.

One of the areas in which this subtle barrier surfaced was in relation to religious affiliations among the Chinese. But before we examine this further, it is important to mention that North Sulawesi Province has always been a Christian stronghold. Since the establishment of the province in 1964, Christians and Muslims have constituted the two main religious communities of the region. Other religions, including Buddhism, have constituted only a tiny minority. The equilibrium between Christianity and Islam became tilted in January 2001, when the Muslim-dominated regency of Gorontalo became a new province. Today, North Sulawesi Province consists of 69 percent Christians and 29 percent Muslims, with the remaining 2 percent comprising Buddhists, 
Hindus and other religious denominations. ${ }^{9}$ The current Christian predominance is one of the reasons why so many Chinese have more or less voluntarily moved to North Sulawesi, especially after the fall of Suharto in May 1998. About 60 percent of the Chinese in North Sulawesi are nominal Christians, while the rest are more or less devoted to Buddhism.

In the North Sulawesi Chinese community, a variety of Christian denominations and Buddhist practices co-exist peacefully. Many elderly Chinese are Buddhists whereas the younger generation tends to be Christian, belonging to denominations such as GMIM, Bethel and Pentecostal, to mention the main ones. In addition, there is a small congregation of Catholics. In relation to Buddhism, there is a 200-year old Taoist temple at the centre of Kampung Cina which most of the Buddhists in this part of Manado attend. When I visited the temple in March 2003, an official told me that in order to be recognized by the authorities during the New Order, they had to put effigies of the three main philosophies of Buddhism (Theravada, Mahayana and Tantrayana) in the temple, even though the temple is specifically dedicated to a Taoist interpretation of Buddhism. These three philosophies are generally referred to as the 'three brothers' or Tri Dharma, namely Buddhism, Taoism and Confucianism. Had this not been done, the temple would not have been allowed to function during the New Order.

This particular Taoist temple is dedicated to T'ien Hou, the southeastern Chinese goddess of the sea and heaven. The relocated Taoist temple on the outskirts of Manado is also dedicated to T'ien Hou and is thus also directed towards the sea. ${ }^{10}$ According to a senior figure at the old temple, about 90 percent of the Buddhists in North Sulawesi are Taoist. The early Chinese traders and settlers brought Taoism with them from Fujian Province in Mainland China more than 200 years ago. This early contact between the pre-colonial cultures in the mountainous interior of the Minahasa regencies and Chinese traders is evidenced by pieces of Chinese porcelain discovered in the old burial tombs, the socalled Warugas, found throughout the Minahasa regencies. ${ }^{11}$

According to the temple official, after the fall of Suharto in May 1998, there emerged some new followers of Taoism, but relatively few in number. When viewed over time, the Taoists comprise quite a stable group. However since 1998, there has been an upsurge in interest in celebrating Buddhist ceremonies, particularly on the part of the younger generation. These young people are not Buddhist, but Christian or Muslim, yet they enjoy participating in some of the major 
Taoist ceremonies. For example, during Cap Go Meh, which means 'Night of the 15th' in Hokkian (it is held on the fifteenth day of the first month of the Lunar Calendar), many young Christian and Muslim men take part in a big parade. ${ }^{12}$ During this festival, effigies of the gods, including T'ien Hou, are carried around the streets of central Manado. It would be very wrong to deduce from this that these young people are converting to Taoism. They maintain their own religion despite participating in another religion's practices. The main motive behind this inter-religious activity can be seen as a reflection of the newly won freedom to worship after Suharto was toppled. During the New Order it was forbidden to celebrate Cap Go Meh in public; Chinese celebrations of this kind were restricted to the private sphere.

In general, Taoism in Manado and throughout the Minahasa regencies in the northern and central parts of North Sulawesi Province is on a good footing with both Muslims and the dominant Christian denominations in the region. This is not surprising, as Buddhism together with Hinduism only represents about 2 percent of the religions practised in North Sulawesi. As such, it does not in any way threaten the dominant position of Christianity.

One factor that might be responsible for keeping down the number of Buddhists is the low profile that Buddhists maintain in social and political matters. This can also be interpreted as a non-engagement approach towards worldly matters, so as not to offend the more vociferous Christian denominations. As a consequence, Taoism and Buddhism in general pursue a rather subdued life compared to Christianity among the Chinese. Given the high profile of Christianity among both ethnic Chinese and Minahasa, it seems to function as a linkage mechanism between the two ethnic groups, thus facilitating an assimilation process. Taoism, on the other hand, tends to isolate its adherents from the Minahasa, exoticizing the former and thereby rendering them as different. Taoists thus constitute an exclusive group that indirectly works against ethnic assimilation, preferring integration as a way of preserving its cultural and religious uniqueness. The Taoist way of life has given rise to an ambiguity in terms of cultural and political loyalty, which makes the Christian Minahasa unsure where to position this ethnic group in their social, political and economic universe. The combination of these factors means that Chinese Buddhists in North Sulawesi Province should more accurately be thought of as integrated rather than assimilated. 


\section{Early Chinese Migration and Family History}

An analysis of the social and cultural background of the Manadonese Chinese will help to establish their place of origin. The majority of the great-grandparents of those who participated in this survey arrived in Manado in the 1930s. Manado is a city with a history stretching back to the early period of Dutch colonization in $1677 .{ }^{13}$ Here they found a thriving Chinese community consisting of 4,770 individuals out of a total Chinese population in the Minahasa region of 7,028. Manado had at that time a population of 28,077 (959 Europeans; 4,770 Chinese/ Asians; and 22,348 Indonesians). ${ }^{14} \mathrm{~A}$ minority of the migrants came to this region because they already had family relations there or knew somebody who could provide them with a job upon arrival. The majority, however, came to North Sulawesi and Minahasa in particular because they had heard that there were good opportunities for doing business there.

The first major Chinese settlements were recorded back in the 1850s. They were located north of a hill, which was east of the Dutch-built Fort Amsterdam, at that time the centre of Manado. The European wards were north and south of the fort while the Alfurs, as the Minahasa people were called at that time, were living east and south of the European and Chinese wards (Nas 1995: 60-61). Manado was then a bustling city with a mixed ethnic business community. It had 7 European, 5 Japanese, 16 Arab, 1 Indian and 43 Chinese stores in addition to an ice factory, 3 tailors, 7 shoemakers and 10 carpenters. Unfortunately, the ethnic affiliations of the latter stores are not detailed in the annals. ${ }^{15}$ This was the Manado that early migrants from our survey encountered when first arriving there in the 1930s.

It was also around that time that Manado saw the largest influx of Chinese migrants. However, this almost came to a standstill when the Second World War engulfed the area in early 1942. The next major influxes of Chinese migrants did not take place until after the fall of Suharto in May 1998. As a consequence of the harassment of the Chinese population in many of the major Indonesian cities during this period, a number of ethnic Chinese went to Manado and North Sulawesi, as the social and political situation there was much more stable and welcoming compared to many other parts of Indonesia. The second and latest influx of ethnic Chinese to Manado and North Sulawesi came after riots broke out in 1999 in the southern and northern parts of Maluku, together with the riots in central and southern Sulawesi respectively. The refugees came with their families, businesses and capital and began to mix with 
the local Chinese community. Many of these Chinese latecomers to North Sulawesi stayed on after the situation in their home regions had improved in terms of social and political stability. Now they regard North Sulawesi as their home because, according to our informants, this region is one of the safest areas in volatile Indonesia.

The migration and family history of the pre-1998 Manadonese Chinese in the clothing, electronics and IT retail sectors, reveals that 81 percent of the original Chinese migrants came directly from Fujian or Guangdong Province in southeast China to Manado, bypassing the political and economic centre of Jakarta. ${ }^{16}$ The remaining 19 percent came from either Fujian or Guangdong Province to Manado via Penang, Jakarta and Makassar. This indicates the continued use of an already established eastern trade route in Southeast Asia, along which migrants could travel en route to the Philippines or further down towards the eastern parts of today's Indonesia.

It was the growing importance of the Melaka mercantilist sultanates in the sixteenth century and their vast maritime trade networks in Southeast Asia which reduced the importance of the eastern trade and migration routes from China to Indonesia. ${ }^{17}$ As generally suggested, the majority of Chinese traders and migrants used the western routes. One possible route could have been along the eastern coast of Vietnam and Malaysia, continuing down via Johore towards Java and from there through the Java Sea towards Makassar or through the Flores and Banda Sea towards Tidore or Ternate before finally ending up in North Sulawesi and Manado, if that were the final destination.

However, since the thirteenth century there existed trade routes that took as their main point of departure Quanzhou in Fujian Province, from there straight down along the western cost of what is now the Philippines, continuing towards Ternate, Tidore and Ambon, and passing through the passage between Sangihe and Talaud islands in today's North Sulawesi. These trade routes continued to be popular until the sixteenth century, when they were more or less abandoned due to shifting political and economic tides in the Southeast Asian region. ${ }^{18}$ Nonetheless, small communities of Chinese merchants established themselves along these old trade routes, thus providing later migrants with points of intersection on their journey towards either Sangihe Island or Manado in North Sulawesi. The foundation for a Chinese diaspora in this part of Southeast Asia was thus laid in the thirteenth century, which migrants in the early twentieth century could capitalize on during their travels. 
It is perhaps important to note that not all migrants went directly to Manado. Some preferred to try out other areas that they had heard about before leaving China for North Sulawesi. For example, one informant's great-grandfather went to Amurang, a town of 13,687 individuals in the 1920s, about $40 \mathrm{~km}$ southwest of Manado. He initially stopped there, as it was one of the major trading towns for copra production. He spent his first years there working as a shop assistant while learning Bahasa Indonesia. After a few years he moved on as a truck driver and finally ended up as a commodity trader. He then moved to Tamako in Sangihe Island, where he opened a number of small wholesale stores between Tamako and Manado. (Sangihe was and still is known for spices such as nutmeg and cloves, together with copra, either as crude coconut oil or as a product in itself.) In between he went to Manado and Surabaya in Java to promote his business. Today his family lives in Manado where they concentrate on pharmaceutical products and licensed production and distribution of soft drinks.

Another example concerns a great-grandfather who went to southern Minahasa where he sat up a wholesale store and copra business close to a prominent goldmine. Here he married a Chinese woman. He made business trips to Manado but always returned to the southern part of Minahasa. The informant's grandfather was born and raised there. In 1950 he and his family moved to Manado, as life there was easier and more conducive for his particular line of business, namely garments. The couple's daughter married a Chinese man and together they had five children; two boys and three girls. Today one of their sons has moved to Sangihe where he runs a clothing store. He is married to a Chinese woman. The rest of the family - that is, the grandfather, his son and wife together with their daughter and son-in-law and their second son and daughter-in-law together with the three unmarried daughters - live together in one house above their old clothing shop in Kampung Cina.

The picture that emerges is that the Chinese migrants did not all end up in Manado but that they spread out throughout the Minahasa region. According to a survey conducted in the early 1920s, besides the 4,770 Chinese in Manado, the Chinese population included 9 in Bantik, 602 in Tonsea, 616 in Tondano and 1,031 in Amurang in the Minahasa region. Moreover, in the neighbouring Bola'ang-Mongondow region, about 70 $\mathrm{km}$ west of Manado, 352 Chinese had settled down. ${ }^{19}$ The Chinese had thus fanned out all over the two major regions in North Sulawesi. It is important to note that the vast majority of the Chinese settled down in towns and cities, partly as a result of Dutch colonial policies and partly 
because the Minahasa jealously guarded their land from being taken over by non-Minahasa people.

Apart from settlers from Fujian and Guangdong Provinces, there is no evidence of immigrants arriving in Manado from other provinces in south-eastern China, or elsewhere in China for that matter. The make-up of the immigrants is reflected in the Chinese languages spoken in Manado in the present day. Hokkien speakers dominate (50 percent), followed by Cantonese (19 percent) and Hakka (7 percent). Interestingly, the Mainland Chinese lingua franca, Mandarin, comes in second (23 percent) among the Chinese languages spoken there. I shall elaborate on that in a moment. There were no Teochius or Hainanese speakers in Manado during the period under investigation (March and June 2003).

The percentage of Cantonese speakers is actually higher than indicated above, as one of my respondents told me that both her father and her husband's father came from Guangdong Province. Originally they spoke Cantonese but then changed to Hokkien, as it was the language of both her mother and mother-in-law. As the majority of Chinese in Manado spoke Hokkien, it forced many Chinese to learn that language, as this example has shown. Otherwise, when working in their stores or interacting with the Minahasa, Bahasa Indonesia was and is the means of communication, which almost all the Chinese informants could speak. It was only the very old Chinese who spoke little or no Bahasa Indonesia, the remaining Chinese had no problems with that language.

There is a generation gap between Chinese and non-Chinese speakers within the Manadonese Chinese community. It is typically the elder generation who still speak one or two Chinese languages, whereas the younger generations speak only a little or none at all. Their main means of communication within the family is Bahasa Indonesia. However, a change seems to have occurred since the time Suharto left the political scene. Courses in Mandarin (not Hokkien, Cantonese or Hakka) are gradually becoming more popular among the younger generation, which is why the percentage of Mandarin speakers is so high in Manado. According to those interviewed, this is not only due to a re-sinification process but also because many young people see Mandarin as an upand-coming business language in Southeast Asia alongside English. Taking a course in Mandarin is thus part of a strategy to gain a foothold in the lucrative Chinese market once it begins to make its presence more strongly felt in the southern part of the Southeast Asian business community - and Manado is aiming at becoming an important part of that community (Jacobsen 2004b). 
Maintaining a positive relationship between the Chinese and the Minahasa in Manado and in North Sulawesi is generally considered to be very important. In contrast to many other parts of Indonesia, 75 percent of the interviewed Chinese said that they had good or very good relations with the Minahasa. The remaining 25 percent were neutral towards the Minahasa, meaning that they thought they were all right but did not mix that much with them. None had negative experiences with the Minahasa. One of the reasons why the Chinese are on such good terms with the Minahasa is related to perceptions of culture. Quite a few informants mentioned that the Minahasa were more straightforward in terms of social interaction compared to, for example, the Javanese on Java. Having such a positive relationship would be almost impossible in, say, Java or South Sulawesi, because of the stratified social history which still lingers on today.

In pre-colonial Minahasa the Alfurs lived in small, non-stratified communities where politically important positions could not be handed down to the next generation. The main reason for this was that leadership was kept and maintained on the basis of personal achievements and not on social status. Furthermore, the social and political landscape was in a continuous state of flux, as local communities related to one another in terms of either alliances or war (Schouten 1998). Because of such culturally defined preconditions, it was easier to mix with the Minahasa, despite the huge cultural differences that existed between the Chinese and Minahasa. Another factor promoting good relations with the Minahasa is Christianity. As mentioned earlier, Christianity bridges and thus facilitates social interaction between the majority of the Chinese and the Minahasa. A contrast was generally made towards the Javanese, as by far the largest majority of them are Muslims, thus making communication between the two ethnic groups difficult. An absolute majority of ethnic Chinese in Indonesia are Christians, which is also true of the Chinese from North Sulawesi. These cultural and religious differences need to be seen too in the context of how the Chinese perceive themselves in terms of descent and ethnic classification.

Beginning with perceptions of local descent, there is a marked difference between the three retail sectors investigated. Seventy-five percent of the respondents from the clothing sector stress that they are related to the local Minahasa in terms of inter-marriage, which results in an overwhelming classification of them as being peranakan. This observation contrasts quite sharply with the statements of those we interviewed in the electronics sector. Here 83 percent stress their 
'pure' Chinese descent, meaning that they do not inter-marry with the Minahasa but prefer to marry with other Manadonese Chinese families. Interestingly, even though they stress this 'pure' Chineseness, they nonetheless classify themselves as peranakan even though, according to the nominal classification, they should classify themselves as totok, as they practise what can be called ethnic endogamy, thereby preserving a perceived Chineseness.

This sounds like a contradiction in terms, but when one looks more deeply into the values that lie behind the two terms peranakan and totok in this particular context, then it is quite logical. The term peranakan implies long-term settlement in the local environment and thus a higher degree of assimilation than the term totok implies. Actually, calling a Manadonese peranakan a totok is almost an insult, as it implies that he or she is a newcomer who does not want to become assimilated, only integrated into a local community. So even though informants from the clothing sector stress inter-ethnic descent and informants from the electronics sector stresses their 'pure' Chinese descent as the background for their good relationship with the Minahasa, both claim that they are peranakan, thus indicating a high degree of social assimilation. Mixed or 'pure' descent and being peranakan thus do not exclude each other, as all three categories refer to the same point of intersection with the Minahasa, namely a long-term settlement and societal involvement in the indigenous Minahasa community.

The informants from the IT sector show a similar pattern. Here there are almost an equal number of Chinese of 'mixed' and 'pure' descent but all stress that they are peranakan. As the IT sector was established around 1995 in Manado, it is the young generation of the long established Manadonese Chinese families who have taken up this business. Therefore we do not find any totok in this sector. The IT sector thus constitutes an outlet for those of the younger generation of Manadonese Chinese who wish to break ranks with the older generations in terms of trade, but who nevertheless still prefer to live and work relatively close to their families and place of origin.

\section{Doing Business in Contemporary Manado}

We have so far established that a majority of the Manadonese Chinese families originated from either Fujian or Guangdong Province in south-eastern China, that a majority came directly to North Sulawesi thus bypassing Jakarta, the political and economic centre of the nation, 
and that they feel themselves highly assimilated into the Minahasa community. This prompts the question of how these circumstances influence the way in which the Chinese do business in Manado. Do they do it on the basis of guanxi relationships, as maintained in the literature on Chinese business practices mentioned in the beginning of this paper, and do the Manadonese Chinese entrepreneurs draw on the Chinese diaspora if they want to expand their business ventures beyond the provincial and national borders?

In order to address these questions, let us return to the survey that was carried out among the Manadonese Chinese entrepreneurs in March and June 2003. Again, the organization of the retail sector follows the previous one used in this article, namely the clothing, electronics and IT retail sectors. Before going into detail, however, let us take a look at how the local non-Chinese business community perceive the Chinese entrepreneurs.

\section{Chinese Entrepreneurs and the Local Business Environment: Local Perspectives on Chinese Business People}

During an interview with one of the three executive chiefs from Kawasan Pengembangan Ekonomi Terpadu (KAPET), or in English 'the Integrated Economic Development Zone: Manado-Bitung', ${ }^{20}$ I enquired about the involvement of Chinese entrepreneurs in this organization and how they fitted into the overall business environment in North Sulawesi. The Chief Executive Officer for KAPET was a Chinese himself, and my informant, a 'pure' Minahasa, claimed that the Chinese were very well integrated into the Minahasa community and as such did not constitute a specific minority group there. Furthermore, the way in which the Chinese conducted their business in this province differed markedly from other parts of Indonesia. There they were very Chinese in terms of business strategies, that is, they mainly worked along guanxi lines, and when conducting their business they were aggressive, and generally did not trust other people, Chinese and non-Chinese alike. The Chinese in North Sulawesi Province, on the other hand, were much more integrated into the local business community and were regarded by local business people as competent traders and trusted partners. Furthermore, some Chinese had married local women, were mostly peranakan and Christian, while a few were Buddhists. As such the Chinese shared many of the same values as the Minahasa and thus did not confine themselves to more or less closed communities like China towns, as in many other parts 
of Indonesia. The latter remark is interesting as this local Manadonese businessman did not conceive of Kampung Cina as a China town. Like the Chinese, he thought of it as just one of many other business centres that make up Manado.

This positive attitude towards the Chinese entrepreneurs also permeated an interview with a representative from the North Sulawesi Chamber of Commerce and Industry. Like most other informants, he said that the Chinese in North Sulawesi Province were very well integrated into the Minahasa communities. They did not set themselves apart as a distinct group, nor were they perceived in those terms by others, for example, the Minahasa. They had become assimilated into the local communities through marrying local women. For example, the mayor of Bitung, the industrial centre of North Sulawesi Province, was Chinese, the Chief Executive Officer of KAPET was also Chinese, and several members of the Chambers of Commerce were Chinese. This is very different, he said, from South Sulawesi Province, where the Chamber of Commerce is exclusively made up of local Muslims. The Chinese are excluded from the Chamber and were thus forced to set up their own Chamber of Commerce. He thought that this disparity was due to differences in religion and cultural history.

In order to further improve and facilitate the relationship between the Chinese business entrepreneurs and the local non-Chinese business community, a new organization has been set up in the form of the Indonesia China Business Council (ICBC). It was established on 29 April 2003 and officially opened by the Chinese ambassador to Indonesia. There are 108 members of ICBC in Manado; 70 percent of them are young Chinese entrepreneurs and the rest are Manadonese businessmen. The ICBC in North Sulawesi constitutes part of a nationwide umbrella organization that covers 12 ICBCs, or departments as they are called, spread throughout Indonesia: Sulawesi has three (North, Central and South Sulawesi); on Java ICBCs can be found in the eastern, central and western parts; and on the island of Sumatra there is one ICBC in Medan. So far there is one in Mainland China, namely in Guangzhou in Guangdong Province. ICBC does not compete with either KAPET or the North Sulawesi Chamber of Commerce and Industry as such. It was actually the latter that prompted the Chinese business community to set up a branch of ICBC, as there was no umbrella association or organization for the wholesale or retail sector in the province. ICBC has taken up this task and this has created a link between the Chinese and Minahasa business communities. 
The chairman of the North Sulawesi ICBC (who runs a motorcycle and car dealership), the vice-chairman (who is in cosmetics and tourism), and the secretary (who owns a fish cannery in Gorontalo Province), all come from Fujian Province and speak Hokkien and Mandarin. They said that many Chinese business people like the chairman had come from South Sulawesi and Jakarta during the late 1990s because of civil unrest there. Compared to where they came from, they were all quite happy to stay in Minahasa, as they felt safe and could conduct their business in peace. Only a very few went back to South Sulawesi and Jakarta after the riots stopped in May and June 1998. It is an interesting twist of history that some of the Chinese business people that came from Jakarta actually originated in Manado and North Sulawesi Province. They had just expanded their businesses to Jakarta but have now returned together with their businesses. All of them talked about North Sulawesi as if the province only consisted of Minahasa people; this was also the case with many non-Chinese. This tells us something about how dominant the Minahasa, conceived of as an ethnic group, are in North Sulawesi Province. The other ethnic groups in the province have in this connection rhetorically been left out of the social composition of the province. ${ }^{21}$

When comparing the views from KAPET and the North Sulawesi Chamber of Commerce and Industry, who represent the two major business facilitators in the province, we find a convergence of statements from both the Chinese and the Minahasa business communities. It is this view that underlies the notion of successful assimilation and cohabitation. There is, however, as shown in the previous discussion of religious affiliation among the two ethnic groups, a subtle degree of difference, which manifests itself when going beyond the rhetoric of assimilation. Before we discuss this issue, let us turn our attention towards some other features within the Chinese business community that will deepen our understanding of how that community is constituted, especially in relation to business strategies.

\section{On the Clothing, Electronics and IT Retail Sector: Common Trends and Developments}

Most of today's Manadonese Chinese retail businesses within the clothing and electronics sectors began as family-owned stores, in the wholesale sector in particular. Here they sold rice, clove, copra, spices and other types of local foodstuffs together with household articles and building materials of all kinds. When a new generation took over the 
stores in the 1970s, 1980s and 1990s, most of them specialized in the retail sector as a way of becoming more competitive in an increasingly complex business environment. Despite these changes of business type, it is still mainly family-run businesses that dominate the clothing and electronics sectors. This means that the majority of members of the owning family are actively engaged in promoting, selling, buying and organizing everyday activities in their respective stores.

The IT sector, a newcomer in the retail sector, originated from a desire on the part of the younger generation to try something different to the traditional products traded by their parents. These stores are less than a decade old and occupy their own niche in commercial Manado, where they mainly sell complete computer solutions to government offices and private businesses. Some of the minor IT stores concentrate on sales to private individuals and offer to repair and upgrade second-hand computer equipment. Today there are about 20 IT stores and companies in Manado and these have organized themselves in a loosely structured network. This provides a vehicle not only for coordinating new business initiatives, but also for exchanging information about anyone who does not follow fair business practices.

Today most families, especially in the clothing and electronics sectors, have more than one store, on average two or three. Some of them have broken out of the confinements of Manado and branched out to other areas in North Sulawesi, for example, to the other main municipalities in the province, Bitung and Tomohon, or even further afield, for example, to Sangihe Island north of mainland North Sulawesi. In relation to the latter, the main reason for choosing this rather remote island was that some of the early Chinese immigrants from Fujian Province passed through that island in the early 1930s. Some of those migrants stayed on, thus providing today's Manadonese Chinese with relatives there. It is especially within the clothing sector that we find these familial connections.

When discussing business strategies and practices, most informants maintained that they did not depend on kinship-affiliated trade relations or guanxi practices but chose suppliers who could provide them with the best price, whether they were Chinese or non-Chinese middlemen, for example, Indian or Indonesian traders. The most important thing for the Chinese informants was what offers there were and whether these fitted into their business profiles. On the basis of such statements, it appears that ethnic affiliation was not the mainstay for doing business in Manado in mid 2003. Of course, if the Chinese informants had family relations 
that were in the same line of business as they were, they would utilize these contacts, but not at any cost. The bottom line in any transaction was the profit margin. As the exception to the rule there are, however, a few Chinese store owners, especially within the clothing and electronics sectors, who prefer to do business exclusively along guanxi lines and buy new goods for their stores exclusively through Chinese middlemen, but they constitute a tiny minority within the Manadonese Chinese business community. Interestingly, in these cases all family members are Buddhist and they regard themselves as being 'pure' Chinese, that is, there are no mixed marriages within these families. They are also the ones who do not mix that much with the Minahasa except when doing business, that is, across the counter so to speak. Otherwise they prefer to confine their social relations to other Manadonese Chinese families.

In relation to the clothing sector, most of the shops do not make clothes themselves but direct their customers to specific tailors, who can be found all over Manado and not just within Kampung Cina. Also in this connection guanxi relations do not dominate business practices. The representatives from the Chinese clothing stores I interviewed directed their customers not only to Chinese tailors but also to non-Chinese ones, that is, Manadonese or Indian - the choice depending on either family or business relations. It is therefore safe to say that guanxi trading relations constitute but one of several business strategies employed by the Manadonese Chinese entrepreneurs in the clothing sector.

When buying new items for their shops, many traders from all three retail sectors went to Jakarta or Surabaya on Java to attend trade fairs and buy, where possible, directly from the factories. One representative from the IT sector said that there was a division between Jakarta and Surabaya in terms of serving the various Indonesian customers. Jakarta concentrated on those from western Indonesia whereas Surabaya concentrated on customers from the eastern parts. If a retailer did not have the opportunity to go to either Jakarta or Surabaya, there was always the option of buying new items through trade agents in Manado. This is particularly true for the electronics sector. At least one of the stores in Manado is an agent for Sony. They sell Sony products to many of the other electronics stores in Kampung Cina. A few of the store owners in the survey, particularly in the clothing and electronic sectors, went abroad, in particular to Guangzhou in Guangdong Province, to attend the big trade fairs. Only a tiny percentage of the informants went to Guangdong or Fujian Province in order to initiate new business contacts. It is mainly the big retail stores that are able to do that; the other stores 
in this survey are too small to afford to practise this strategy. However, there are plenty of other avenues for expanding one's business locally, as demonstrated by the new shopping malls along Manado Boulevard.

An interesting thing in this connection is that when Manadonese Chinese visit either Guangdong or Fujian Provinces, hardly any of them visit what family they might have left there. Many maintained that they had lost contact with their original families, which they did not consider as a great personal loss. As a consequence, they attend the trade fairs strictly for business; alternatively they may visit the province of origin or other parts of China as tourists with sightseeing as the prime aim of the trip.

Despite all the talk of a successful inter-ethnic assimilation process, the Manadonese Chinese business community is generally inward oriented, that is, they do not enter into inter-ethnic business ventures. This is evidenced by the fact that none of the store owners interviewed had any plans to involve Minahasa business people in their future business ventures. They often expressed a lack of conviction in the capabilities of the Minahasa. Another reason could be that in general the Minahasa prefer to take up positions within the political and administrative establishment. Given this preference, a conflict of interest for such inter-ethnic joint ventures could arise. Furthermore, none of the store owners had any relations with the provincial authorities, especially the provincial planning board, the North Sulawesi Chamber of Commerce and Industry or KAPET, even though the latter two organizations are the major business facilitators in the province. This might, however, have something to do with the type and scale of businesses under investigation here, as there are Chinese business people among the boards of directors in both organizations.

All of the Manadonese Chinese store owners (except a few within the IT retail sector) who participated in this survey maintained that they had no need for these organizations and that they preferred to work on their own initiative and according to their own business plans. Beyond that, the Chinese business community provides them with all the business and financial infrastructure they need. The exception consists of a few store owners within the IT retail sector, as they need a recommendation from the North Sulawesi Chamber of Commerce and Industry to obtain contracts for selling turn-key computer solutions to various government offices. This was the only contact they had with the official business establishment. 


\section{Kongsi-based business practices}

Kongsi business organizations provide a good example of the selffinancing aspect of the Manadonese Chinese business community. They also highlight the introverted nature of that community, which, according to informants, is quite a common phenomenon within the Manadonese Chinese business environment. For a start, the word kongsi means 'to share' and in contemporary business terminology it usually refers to family members pooling money in order to establish a familycontrolled business. The profit generated by a kongsi business is divided annually or sometimes monthly between those family members who originally contributed to the establishment of it. The definition of the term kongsi in relation to both pooling resources and sharing (revenues) hints at an origin beyond the business context. This puts it in the same category as the term guanxi, which also has its origin outside a business context in a modern sense of that word. ${ }^{22}$ For example, Barbara Ward wrote in 1954 that:

The Kongsi system had its roots in the village organisation of China. Those who see it as something apart, without recognising its connection with the basic Chinese social structure and with the historical and geographical environment in which it developed, tend to fall into one or other of two errors. Either they see the Kongsi as a secret society, conspiring to thwart all regular civil government, in which case they condemn it; or they see it as a prototype of modern republican democracy, in which case they eulogise it. Both views are misconceived. As de Groot was at such pains to prove, the Kongsi system was naturally developed out of the experience of Chinese immigrants, coming in compact clan and village groups to a strange land in which they had to fend in all matters completely for themselves (Ward 1954: 360).

Bien Chiang warns, however, that references to the egalitarian and democratic spirit of kongsi organizations are embedded in an early developmental stage of that practice; he stresses that this quality was not feasible in its later stages of development (Bien Chiang 2003).The difficulty in maintaining an authentic, ethnically affiliated group after migrating from the father/motherland and arriving in a foreign cultural and political economic environment forced people over time to rely on more voluntary types of kongsi organizations, thus altering the internal dynamics of kongsi altogether (Bien Chiang 2003: 5). Bien substantiates his argument by citing Carl Trocki:

The Kongsi changed shape as it came to terms with European capitalism in the nineteenth century, with the Chinese adopting some European business 
practices; thus the Kongsi gained a degree of legal status while at the same time maintaining some of their original characteristics (Trocki 1997)

The Chinese retail businesses in present-day Manado that claim to be based on kongsi principles fall into the latter definition, as outlined by Trocki. Several different types and sizes of Chinese companies in Manado have started in this way, as the individual founder of the business tends to lack sufficient capital to start up on his own. As one informant explained: 'If I want to start a business but don't have an office and don't have enough money to rent one, I ask my uncle to borrow a room in one of his buildings. Instead of paying him a rent I give him a share in the profit, which will be split annually. ${ }^{23}$ He continued by saying that these kongsi-based businesses usually do not last long because as the business grows, some of the people who originally contributed to it financially or otherwise might suddenly want to take over the company. If this is not possible, they may threaten to pull their money out of the business, thus forcing it to collapse. In this context, kongsi practices can lead to serious conflicts within the company and, ultimately, within the family.

From an anthropological and sociological point of view, because of the socially sensitive nature of this type of business venture, kongsi is best practised between either very good friends or close relatives. As such, kongsi-based businesses are problematic compared to other types of businesses that are based on more general capitalist practices. Furthermore, if kongsi businesses are also based on guanxi relations in an attempt to facilitate common business interests, this can increase the potential for conflict between the founders of the business; for example, due to different perceptions of what the right business strategy should be. If such tensions cannot be contained or resolved among the shareholders, then all sorts of problems can arise, as the legal basis for this type of business venture is not as well developed as in ordinary business practices. This is not to say that kongsi practices do not fit general capitalist modes of doing business, however, they do entail higher risks on both a business and family level.

Finally, a major new development has to be taken into account, whether the discussion focuses on kongsi or guanxi modes of doing business within the Manadonese Chinese business community, or on inter-ethnic assimilation processes and how these affect the way the Chinese do business in North Sulawesi. I am here referring to the introduction on 1 January 2001 of the national programme of economic decentralization and regional autonomy. I have discussed elsewhere the implementation of this decentralization programme in another 
context (Jacobsen 2004a). Here I shall only mention in passing that all the informants from the three retail sectors maintained that this new decentralization scheme had made things more complicated in terms of doing business in the province. During the Suharto era there were at least some rules and regulations that could be exploited or manipulated to their advantage, but this is no longer the case. Now it is not just the various agencies within the central government that need to be approached but also the provincial, regional and/or municipality and their bureaucracies. The informants' main concern focused on new tax regulations, which have become very complicated and costly for many businesses. Several Chinese informants complained about double taxation as the provincial government, the regency, and the municipality all demand taxes from them. As such they would be in favour of the abolition of the decentralization scheme as it has become an impediment for most types of businesses, small and big alike.

It is still too early to assess what kinds of consequences these new constraints will have, especially on Manadonese Chinese business practices. Perhaps they will reinforce the conservative forces within the Chinese business community, thus reinvigorating the use of kongsi and guanxi practices in order to circumvent the official bureaucracy. On the other hand, such a reversal of business practices would run counter to a growing globalization of the economy, thereby jeopardizing the expansion and ambitions of many within the Chinese business community. What is certain is that a reorganization of the Manadonese business environment, regardless of whether it is the Chinese or the local Manadonese one, is imperative if a vibrant and dynamic economy is to survive in such a changeable and politically volatile landscape.

\section{Conclusion}

Two principal characteristics emerge when studying the Manadonese Chinese business community. The first is the much emphasized rhetoric of inter-ethnic assimilation in the Manado-Minahasa communities - a preferred Chinese societal positioning that is underlined by referring to oneself as a peranakan. Stressing assimilation instead of integration and categorizing oneself as peranakan is similar to stressing both a diachronic and synchronic sense of belonging. Being a peranakan means having roots in the local community, while being assimilated refers to an abolition of ethnic differences. At face value, these two aspects of being Manadonese Chinese constitute some of the factors behind the unusually 
(in an Indonesian context) low level of clashes between Chinese and Indonesians both before and after the fall of the New Order regime.

The second thing about the Manadonese Chinese is that they do not stand out as a distinct ethnic group among the Minahasa. On the contrary, even the Minahasa stress the almost total assimilation of the Chinese into the local communities. To a large extent this can be attributed to the fact that the mechanisms for marking oneself out as a distinct ethnic group do not play a role in the inner functions of the Manadonese Chinese. For example, guanxi relations and connections to a transnational Chinese (diasporic) community do not figure highly in the Manadonese Chinese business community, even though they can still be identified as a social signifier. As such, this study subscribes to Gomez and Hsiao's critique of the role of guanxi relations in a market economy. As stressed several times in this article, it is profit that is the touchstone for the Manadonese Chinese entrepreneurs when conducting business, not ethnic factors or cultural preferences. Because of this, I lend support to Dirlik's general proposition that guanxi in a contemporary business context is more about a rhetorically dictated ethnification of capitalist practices than a real issue when engaging in actual business. Kongsi organizations and guanxi relations are thus only invoked if they can lead towards higher or more stable profit margins. In this sense, continually stressing guanxi as a dominating aspect of Chinese business practices, at least in Manado, can be criticized as a kind of cultural chauvinism within a specific business discourse.

There is one further interesting consequence of the non-dominant position of guanxi in the Manadonese Chinese business community. Because it is so weak, guanxi actually undermines the functioning and effectiveness of kongsi-organized businesses. Arguably, guanxi relations can be conceived of as reinforcing the inner workings of kongsi businesses, as both strive towards reinforcing relations between the Chinese partners and thus indirectly promoting a distinct Chineseness in terms of business practices. However, guanxi constitutes only one of several business strategies when establishing kongsi-based companies. This de-linking of the relationship between guanxi and kongsi thus reinforces processes of assimilation and downplays the development of a distinct ethnic Chinese identity. This development is underscored by another factor, namely religious affiliations, as Christianity is generally seen as a facilitator between non-Buddhist Chinese and Christian Minahasa. And as Christian Chinese by far outnumber the Buddhist Chinese, processes of assimilation are further reinforced. 
However, if we were to take the processes of assimilation to their ultimate limit, we would arrive at another assumption, namely that distinctive ethnic features would become hybridized to such an extent that the original ethnic identity would disappear. Moreover, that when this happens, a new common cultural denominator would arise. Such a viewpoint can only be a naïve illusion; assimilation processes are always based on asymmetrical relationships. In the case of the Manadonese Chinese and the Minahasa, the latter forms the dominant party and it is impossible to imagine that they would relinquish one iota of their perceived ethnic supremacy in relation to the Chinese. Processes of assimilation can thus only be a means to an end and never an end product in itself. They help to formulate the power relations that are manifested in social integration and that more or less peacefully co-exist. Ethnic distinctions remain, despite these processes, but become subsumed at a lower level of social practice. They only resurface during ceremonial occasions, which are socially acceptable to the dominant 'other'. This is why the Manadonese Chinese can celebrate their 'traditional' customs, as the latter are viewed by the dominant 'other' as socially detached, exotic fabrications that do not impinge in any fundamental way on the established societal hierarchy.

A somewhat unexpected consequence of these processes is that the Manadonese Chinese have become dissociated from the Chinese diaspora. As we have seen, by far the greatest numbers of informants have detached themselves from their ancestral roots in either Fujian or Guangdong Province. China has been transformed in their worldview into a specific trading centre and/or interesting tourist destination. The 'home' part of the Chinese diaspora has been separated from the otherwise classical triangular perception of diasporic manifestations, namely the 'home-host-migrant' construct. This points towards the fact that diasporas are multi-dimensional entities that are contextually defined. Even though the Manadonese Chinese have severed the link to the 'home' part of the Chinese diaspora, the latter is still there. The linkages that it represents are still there. For example, coming to either Sangihe or Manado in the 1920s was more or less determined on the basis of pre-existing links between Chinese communities in southern China, the Philippines, and the Maluku. And the continued use of kongsi-based businesses also presupposes the existence of Chinese communities in those places where a daughter company or a new store is being established. In this connection it does not matter whether we are talking about national or transnational aspects of a given diaspora. 
However, when not activated, the diasporic link withdraws into the deep recesses of people's consciousness and remains there until various social and political events reboot it back into existence.

It is therefore possible to maintain that a diaspora is a latent structure, that is, not a permanently established, ethnically oriented national or international router for migrant and sojourners. A diaspora only comes back to life locally when certain social, political or economic events exert pressure on a certain ethnic group, for example, the Chinese, as has been the case several times in Indonesia. This confirms Riggs's notion of diasporization and de-diasporization, as people utilize a given diaspora when the need arises (Riggs 2001). This is obviously the case for the 'old' and 'new' Manadonese Chinese. For now, North Sulawesi Province provides them with a social and political safe haven, and the Minahasa accept them in their midst as they constitute an important economic factor in the province. So for the time being, the Manadonese Chinese are highly localized, that is, assimilated and thus de-linked from the Chinese diaspora. How long these harmonious inter-ethnic relationships will last depends on a whole range of things: economic performance, both locally and nationally, religious harmony, and amicable and noncompetitive inter-ethnic relationships, to mention just a few areas of potential conflict. When and why a shift in these relationships might occur, thereby giving rise to a potential re-linking of the Manadonese Chinese to the Chinese diaspora, can only be determined through empirical studies, not theoretical extrapolations.

Michael Jacobsen is Associate Professor at Asia Research Centre, Copenhagen Business Schooll

\section{NOTES}

${ }^{1}$ I would like to thank the Southeast Asia Research Centre at City University of Hong Kong for financing the fieldwork on which this article is based. I furthermore thank Stephen Frost for having made many useful suggestions regarding this paper. A warm thanks goes to my friend and mentor Prof. Willem Waworoentoe for his kind help in providing me with data otherwise inaccessible to me. Finally, I would like to thank the two anonymous readers for constructive comments and criticism. Needless to say, I am responsible for the different extrapolations and conclusions offered here.

2 Guanxi constitutes a form of social exchange between individuals that is founded on sentiments and emotions marked by a belief in mutual reciprocity and loyalty.

3 For an interesting discussion in this connection, see Ang (2001) and Riggs (2001).

4 For a detailed account of Minahasa identity, see Jacobsen (2002).

5 Peranakan refers to ethnic Chinese who have developed a creolized or mestizo culture 
with strong Indonesian characteristics. These Chinese are descendants from early immigrants to Indonesia, traders or indentured labourers imported by the Dutch during the early colonial period. The most important characteristics of the Peranakans are that they, that is, the men, initially married (and to a certain degree still do) local Indonesian women due to (originally) a lack of Chinese women or (today) because of inter-ethnically strategic reasons, and that they speak Bahasa Indonesia within the family. Proficiency in Chinese languages and knowledge of traditional Chinese culture have gradually disappeared. Today most Peranakans do not speak, read or write Chinese. The term Totok refers to relatively recent Chinese immigrants to Indonesia. They have lived in Indonesia for about one generation, speak one or two Chinese languages, and practise traditional Chinese customs within the family. Both Peranakans and Totoks in Manado represent mainly Hokkien and Cantonese speaking Chinese. Hakka is only spoken by a tiny fraction of the Manadonese Chinese community. Representatives of the other two main Chinese languages found in Indonesia, Teochius and Hainanese, did not exist in Manado at the time of the study.

6 These three types of retail sectors are chosen because they combine new and old business sectors, with clothing being the oldest one and IT the newest one. They thus provide us with an insight into the changing circumstances and preconditions for doing business in this part of the retail sector.

7 This sense of superiority is not confined to the South Sulawesi Chinese. The Siauw Giap refers to a study carried out in eastern Java that revealed that no less that 83 percent of the Chinese Muslims who had converted to Islam had been ostracized by their family. The main reason was that their Buddhist or Christian Chinese relatives thought that by converting to Islam they would become poor like the Javanese. See The Siauw Giap (1993). The Chinese Muslims were thus seen as endangering the societal position of other non-Muslim Chinese as well as offending the latter's sense of ethnic identity and religious affiliation.

8 During the early 1950s, the Indonesian government decided to force the ethnic Chinese to make a choice of being citizens in either Indonesia or China. This resulted in the Sino-Indonesian Treaty on Dual Nationality, signed in Bandung on 22 April 1955. This decreed that the ethnic Chinese had to choose which nationality they preferred during the period January 1960 to January 1962. Most of the about one million ethnic Chinese with dual nationality registered and out of those, 65 percent opted for Indonesian citizenship. In practice, this meant a huge exodus of ethnic Chinese, about 400,000 people, from Indonesia, heading towards the new Chinese nation (see Tan 1997). The other major impact on the ethnic Chinese community was the killings in 1965 to 1966 when Suharto took power. Many Chinese were lost in that mayhem although their numbers were minute compared to the slaughter of ethnic Indonesians deemed communist at that time.

9 For further details, see Jacobsen (2004a).

10 The reason it was possible to build a new temple during 1997, where such activities were banned by the New Order regime, was that it was a relocation of an old temple and not the building of a new one.

11 For details, see Dalrymple (1995).

12 Cap Go Meh celebrations in Indonesia have their roots in southern China which was the origin of most Chinese descendants. It is believed that on this particular day the gods come out of heaven to grant wishes and spread good luck. Lanterns, which are believed to draw the gods from heaven, are lit so as to lure the gods to the celebrations on earth and lead them back afterward.

13 For more details on the early history of Manado, see Nas (1995). 
14 The above and following figures have been kindly provided by Prof. Willem Waworoentoe. They are compiled from a report written by V.I. van Marle. Verslag eener Spoorwegverkenning in de afdeeling Menado (Personal communication, October 2003). In the 1920s the combined population figure of Minahasa and Bola'ang-Mongondow, the two main regions in North Sulawesi at that time, was about 292,449. According to a population census in 2000, the regencies of Minahasa and Bola'angMongondow had a population of 1,198,529 or 61 percent of a total population in North Sulawesi Province of 1,972,738.

15 From personal communication with Prof. Willem Waworoentoe in October 2003.

16 The migrants from Fujian are numerically better represented that the migrants from Guangdong.

17 See for example Ward (1954); Reid (1996); Ptak (1992); and Thomaz (1996).

18 Ptak (1992), for a detailed overview see Jacobsen (2005).

19 Personal communication, Willem Waworoentoe, June 2003.

20 KAPET was established by the central government in January 1998 and was designed to accelerate economic development in outer Indonesia. Its main function was and still is to provide a favourable business infrastructure in the region and to act as a facilitator of private business initiatives. Thirteen KAPET institutions were initially sat up and Sulawesi got four of them, one in each of the provinces. The new province, Gorontalo, has still not got one, as it was only established in January 2001. The implementation of the KAPETS was a kind of concession towards outer Indonesia in terms of economic development, as in particular eastern Indonesia was more in need of such an input than western Indonesia. The latter has always had the attention of the central government because of a bigger population concentration and a much larger pool of natural resources.

21 For more details, see Jacobsen (2004a).

22 For details on the origin of the term 'guanxi' see Yao (2002: 236).

23 Personal communication, June 2003.

\section{REFERENCES}

Ang, Ien 2001. On Not Speaking Chinese. Living Between Asia and the West. London: Routledge, 2001.

Bien Chiang 2003. 'The Kongsi's Past as a Foreign Country'. Paper presented at a seminar, the Institute of Anthropology, National Tsing Hua University, Taiwan, 8 October 2003. Accessed 11 November 2004 at: <http://www.cckf.org/PrincetonWorkshop/Bien\%20Chiang.doc>

Bolt, Paul J. 2000. China and Southeast Asia's Ethnic Chinese: State and Diaspora in Contemporary Asia. Westport: Praeger.

Callahan, William A. 2002. Diaspora, Cosmopolitanism and Nationalism: Overseas Chinese and Neo-nationalism in China and Thailand, Working Paper Series No. 35. Hong Kong: City University of Hong Kong, Southeast Asia Research Centre, November.

Dalrymple, R. Elizabeth 1995. The Waruga Burial Tombs of North Sulawesi (File number Lg51368). Leiden: Koninklijk Instituut von Taal-, Land- en Volkerkunde: 267-72.

Dirlik, Arif 1996. 'Critical Reflections on "Chinese Capitalism" as a Paradigm.' In R. Ampalavanar Brown (ed.), Chinese Business Enterprise, Vol. I. London: Routledge: 17-38.

Gomez, Edmund T. and Hsin-Huang Hsiao 2001. Chinese Business in Southeast Asia: Contesting Cultural Explanations, Researching Entrepreneurship. Richmond: Curzon Press. 
Hamilton, Gary G. 1999. Cosmopolitan Capitalist. Seattle: University of Washington Press.

Jacobsen, Michael 2002. 'On the Question of Contemporary Identity in Minahasa, North Sulawesi Province, Indonesia.' Asian Anthropology, 1: 31-58.

- 2004a. 'On Factionalism and Secessionism in North Sulawesi: Delineating Emerging Fault-lines in Contemporary Indonesia.' Asian Journal of Political Science, June: 16.

- 2004b. 'Tightening the Unitary State. The Inner Workings of Indonesian Regional Autonomy.' Indonesian Quarterly 32 (4): 384-404.

- 2005. 'Islam and Processes of Minorisation among Ethnic Chinese in Indonesia: Oscillating between Faith and Political Economic Expediency.' Asian Ethnicity 6 (2): 71-87.

Kotkin, Joel 1992. Tribes: How Race, Religion, and Identity Determine Success in the New Global Economy. New York: Random House.

McKeown, Adam 2001. Chinese Migrant Networks and Cultural Change: Peru, Chicago, Hawaii, 1900-1936. Chicago: The University of Chicago Press.

Li Ji and Wright, Philip C. 1999 The Issue of Guanxi: Discrepancies, Reality and Implications. Hong Kong: Hong Kong Baptist University, School of Business, Business Research Centre.

Luo Yadong 2000. Guanxi and Business. Singapore: World Scientific.

Nas, Peter 1995. 'Miniatures of Manado: Images of a Peripheral Settlement.' In Reimar Schefold (ed.), Minahasa Past and Present. Tradition and Transition in an Outer Island Region of Indonesia, Vol. 28. CNWS Publications: 58-71.

Ptak, Roderich 1992. 'The Northern Trade Route to the Spice Islands: South China SeaSulu Zone-North Moluccas.' Archipel 43: 25-49.

Redding, Gordon 1993. The Spirit of Chinese Capitalism. Berlin, New York: Walter de Gruyter.

Reid, Anthony 1996. 'Flows and Seepages in the Long-term Chinese Interaction with Southeast Asia.' In Anthony Reid (ed.), Sojourners and Settlers. Histories of Southeast Asia and the Chinese. St. Leonards: Allen \& Unwin: 15-50.

Riggs, Fred W. 2001. Glocalization, Diaspora and Area Studies: 1-4. Accessed at: <http:/ / www2.hawaii.edu/ fredr/glocal.htm>

Schouten, Mieke 1998. Minahasa Metamorphoses: Leadership and Social Mobility in a Southeast Asian Society: Minahasa, 1677-1983. Leiden: KITLV Press.

Tan Mely G. 1997. 'The Ethnic Chinese in Indonesia: Issues of Identity.' In Leo Suryadinata (ed.), Ethnic Chinese as Southeast Asians. Singapore: Institute of Southeast Asian Studies: 33-5.

The Siauw Giap 1993. 'Islam and Chinese Assimilation in Indonesia and Malaysia.' In Cheu Hock Tong (ed.), Chinese Beliefs and Practices in Southeast Asia. Petaling Jaya: Pelanduk Publications: 83.

Thomaz, Luis Filipe F.R. 1996. 'Melaka and Its Merchant Communities at the Turn of the Sixteenth Century.' In Denys Lombard and Jean Aubin (eds), Asian Merchants and Businessmen in the Indian Ocean and the China Sea. Oxford: Oxford University Press: 25-39.

Trocki, Carl A. 1997. 'Boundaries and Transgression: Chinese Enterprise in Eighteenthand Nineteenth-Century Southeast Asia.' In Aihwa Ong and Donald Nonini (eds), The Cultural Politics of Modern Chinese Transnationalism. New York: Routledge: 68.

Ward, Barbara 1954. 'A Hakka kongsi in Borneo.' Journal of Oriental Studies (Hong Kong) 1 (2): 358-70.

Weidenbaum, Murray L. and Hughes, Samuel 1996. The Bamboo Network. How Expatriate Chinese Entrepreneurs Are Creating a New Economic Superpower in Asia. London: The Free Press. 
Michael Jacobsen

Yang Mei-hui 1994. Gifts, Favours, and Banquets: the Art of Social Relationships in China. Ithaca, NY: Cornell University Press.

Yao, Souchou (2002), 'Confucian Capitalism. Discourse, Practice and the Myth of Chinese Enterprise'. New York: Routledge/Curzon.

Yeung, Henry Wai-chung 1998. 'Under Siege? Economic Globalisation and Chinese Business in Southeast Asia.' PROSEA Occasional Paper No. 21. June.

- 2004. Chinese Capitalism in a Global Era. Towards Hybrid Capitalism. London: Routledge. 